Article - Food/Feed Science and Technology

\title{
Antioxidant Activities of Chicken Egg White Hydrolysates Obtained by New Purified Protease of Aspergillus avenaceus URM 6706
}

Anna Carolina da Silva ${ }^{1}$

https://orcid.org/0000-0001-6272-6147

\author{
Alana Emilia Soares de França Queiroz ${ }^{2}$ \\ https://orcid.org/0000-0002-8603-6076 \\ João Tiago Correia Oliveira ${ }^{3}$ \\ https://orcid.org/0000-0001-7469-5106 \\ Erika Valente Medeiros ${ }^{1}$ \\ https://orcid.org/0000-0001-5543-9414 \\ Cristina Maria de Souza-Motta ${ }^{4}$ \\ https://orcid.org/0000-0002-0964-8271
}

\section{Keila Aparecida Moreira ${ }^{1}$}

https://orcid.org/0000-0002-7715-9285

\begin{abstract}
${ }^{1}$ Federal Rural University of Pernambuco, Garanhuns Academic Unit, Garanhuns, PE, Brazil; ${ }^{2}$ Federal Rural University of Pernambuco, Department of Animal Science, Recife, PE, Brazil; ${ }^{3}$ Federal University of South and Southeast Pará, Institute of Humid Tropics Studies, Xinguara, PA, Brazil; ${ }^{4}$ Federal University of Pernambuco, Department of Mycology, Recife, PE, Brazil.
\end{abstract}

Received: 2018.02.08; Accepted: 2019.07.08.

*Correspondence: moreirakeila@hotmail.com; Tel.: +5587 37645581; Fax: 37645500 (K.A.M.).

\section{HIGHLIGHTS}

- Is the first report about protease production by Aspergillus avenaceus URM 6706

- Aspergillus avenaceus URM 6706 is from Caatinga, a specific biome of the Brazil

- The protease is stable in broad $\mathrm{pH}$ range and temperature

- Protease had great performance at presence of ions, oxidizing agent and surfactants

Abstract: Protein hydrolysates originating from egg white have already been reported to be bioactive and, among their biological activities, possess the antioxidant property that protects the body from early ageing and diseases linked to oxidation. Therefore, the objective of this work was to evaluate the antioxidant activity of hydrolysates obtained by the hydrolysis of egg 
white from hen poultry. The protease produced by Aspergillus avenaceus URM 6706 was purified and subsequently applied to hydrolysate the egg white, and the degree of hydrolysis was verified during the protease exposure time (4-24 h). The hydrolysis was intensified over time of exposure to the protease. It was possible to detect the antioxidant activities of eliminating the 2,2'-azino-bis (3-ethylbenzothiazoline-6-sulphonic acid) radical (ABTS ${ }^{+}$) from $97 \%$ to $99 \%$ and 2,2-diphenyl-1-picrylhydrazyl (DPPH') up to $27 \%$, as well as the chelation of $\mathrm{Cu}^{2+}$ metal ions up to $62 \%$ and $\mathrm{Fe}^{2+}$ up to $54 \%$. The elimination of $\mathrm{ABTS}{ }^{\cdot+}$ radical had a positive correlation with the degree of hydrolysis; however, all the other activities tested showed a negative correlation with the degree of hydrolysis. The results obtained suggest that the egg white of hen chicken represents a food source of animal origin with potential application in the functional food industry.

Keywords: Aspergillus; purification; ABTS ${ }^{\bullet+}$; DPPH ; chelators.

\section{INTRODUCTION}

The oxidative process has an important interference in the health and quality of organisms and food. One of the side effects of oxidative metabolism, being essential for cell survival, is the production of free radicals and reactive oxygen species. When an excess of free radicals is formed, the action of protective enzymes is impaired, which causes destructive and lethal cellular effects on cells, such as apoptosis by oxidation of cellular proteins, membrane lipids, DNA and enzymes, thus causing cell and tissue damage [1-2].

Reactive oxygen species and free radicals are involved in the establishment of various diseases such as cancer, diabetes, Alzheimer's disease, neurodegenerative disorders, hypertension, inflammatory processes and Parkinson's disease, in addition to accelerating ageing. Therefore, the demand for natural bioactive compounds with antioxidant, immunomodulatory and antimicrobial properties and other sources from food is an area that has grown in recent years, being the focus of scientific research worldwide [2].

The benefits of using hydrolysates of food-borne proteins with multiple biological activities have been confirmed by several studies, which have demonstrated the antihypertensive, antioxidant and anti-lipemic activities of peptides obtained by the hydrolysis of egg white [3-4]. Hydrolysis of egg white proteins, for example, may result in the release of bioactive peptides or the enhancement of their biological activity, such as antioxidant activities [5-6].

Chicken egg white is an excellent source of high-quality proteins and is also a good source of bioactive peptides. Generally, one or several proteases are used to prepare proteins hydrolysate [7]. Many commercial proteases, such as pepsin and trypsin, have been employed for this purpose [8]. However, there is interest in the discovery of new microbial proteases produced by fermentation processes, including Aspergillus species [9], which may culminate in the emergence of different peptides with different biological activities from the selective hydrolysis.

However, such functional properties of bioactive peptides may be affected by the modification of the protein structure, including amino acid sequence and composition, molecular mass and charge distribution in the molecule. Thus, enzymatic hydrolysis under controlled conditions is an effective way of improving the functional properties of proteins without affecting their nutritional value [10].

Therefore, the aim of this work was producing, purifying and partially characterizing the new protease produced by Aspergillus avenaceus URM 6706, to be applied in the hydrolysis of egg white under controlled conditions and evaluate the effect of the degree of hydrolysis, as a function of the hydrolysis time of poultry egg white, under the release of peptides with antioxidant activities by the action of microbial protease. 


\section{MATERIALS AND METHODS}

\section{Production and purification of protease}

The protease used in the hydrolysis of egg white from organic chicken was produced by Aspergillus avenaceus URM 6706 from the Department of Mycology of the Federal University of Pernambuco, Brazil. The production was performed by submerged fermentation in $250 \mathrm{~mL}$ Erlenmeyer flasks containing $50 \mathrm{~mL}$ of medium composed of $1.0 \% \mathrm{w} / \mathrm{v}$ of soybean meal and $0.5 \%$ of glucose and inoculated with $10^{6}$ spores. $\mathrm{mL}^{-1}$, at $28^{\circ} \mathrm{C}$ and $120 \mathrm{rpm}$ for $72 \mathrm{~h}$.

Protease purification was carried out in two steps; the first by protein precipitation using different concentrations of ethyl alcohol $\left(0-40 \%, 40-60 \%\right.$ and $60-80 \%$, v/v) at $4^{\circ} \mathrm{C}$ on a magnetic stirrer (at the lowest rotation possible). Then, the second purification step, ion exchange chromatography, was carried out using the pre-packaged HiTrap Q Sepharose FF (GE ${ }^{\circledR}$ Healthcare) column; the mobile phase consisted of Tris- $\mathrm{HCl}$ buffer ( $\mathrm{pH} 7.2$ and $20 \mathrm{mM}$ ), and elution of the enzyme was performed with $\mathrm{NaCl}(0.1-1.0 \mathrm{M})$.

Purity analysis was performed through high performance liquid chromatography (HPLC) using the C18 column $(250 \times 4.6 \mathrm{~mm})$ with $5-\mu \mathrm{m}$ particle size (Phenomenex, Torrance, California, U.S.A.) connected to HPLC Model LC20A, Prominence (Shimadzu, Japan). The mobile phase was made up of trifluoroacetic acid $(0.1 \%)$, and the elution was done in a concentration gradient of acetonitrile (0-30\%) plus $0.1 \%$ trifluoroacetic acid. The absorbance of the eluent was monitored by SPD-M20A, Prominence (Shimadzu, Japan) photodiode array at $280 \mathrm{~nm}$, and the stream was maintained at $0.5 \mathrm{~mL} \cdot \mathrm{min}^{-1}$ for 20 min running [11].

\section{Protease activity}

The evaluation of proteolytic activity was developed by Leighton et al. [12] with some modifications by adding $100 \mu \mathrm{L}$ of azocasein $(1.0 \%$ in Tris- $\mathrm{HCl}$ buffer) to $60 \mu \mathrm{L}$ of enzyme extract. The reaction mixture was incubated for $1 \mathrm{~h}$ at room temperature and stopped by adding $480 \mu \mathrm{L}$ of trichloroacetic acid (TCA) at $10 \%(\mathrm{w} / \mathrm{v})$, followed by centrifugation for 5 min at $8,000 \mathrm{~g}$ $\left(\right.$ at $4^{\circ} \mathrm{C}$ ). From the supernatant, a volume of $320 \mu \mathrm{L}$ was removed and added to $560 \mu \mathrm{L}$ of $\mathrm{NaOH}(1 \mathrm{M})$. One unit $(U)$ of enzyme activity was defined as the amount of enzyme capable of hydrolysing azocasein, providing an increase of $0.01 \mathrm{U}$ of absorbance per minute at $440 \mathrm{~nm}$.

\section{Determination of the total protein content in the enzyme extract}

The Bradford method [13] was used to quantify the total protein content, which was modified to incorporate Coomassie brilliant blue. The calibration curve was designed from stock solutions of bovine serum albumin at a concentration range of $0-600 \mu \mathrm{g} \cdot \mathrm{mL}^{-1}$. The solutions were subjected to absorbance reading at $595 \mathrm{~nm}$ in a spectrophotometer (Biochrom Libra S6®, Cambridge, UK).

\section{Optimum temperature and $\mathrm{pH}$ determination}

The optimum temperature of the pure enzyme produced by $A$. avenaceus URM 6706 was determined by analysing the protease activity at different temperatures $\left(30-80^{\circ} \mathrm{C}\right)$, and the optimum $\mathrm{pH}$ was determined using different $0.2 \mathrm{M}$ buffers as follows: sodium, $\mathrm{Tris}-\mathrm{HCl}$ and carbonate-bicarbonate in the $\mathrm{pH}$ range of 5.0-11.0.

\section{SDS-PAGE and Zymogram}

SDS-PAGE was performed on a polyacrylamide gel according to the method of Laemmli [14] using a gel of concentration at $4.9 \%$ and separation at $15.4 \%$ of monomer. The molecular mass of the bands was determined by Lablmage 1D software (Loccus Biotechnology, Brazil).

For the zymogram analysis, $0.2 \%$ albumin was added to the separation gel. Denaturing substances were withdrawn from the sample buffer, and the content to be analysed was not boiled. After the run, the gel was incubated twice in 1\% Triton X-100 solution for 30 min each. It was then washed three times for $20 \mathrm{~min}$ in distilled water to remove the excess Triton X-100 and then incubated for $60 \mathrm{~min}$ in $0.2 \mathrm{M}$ phosphate buffer $(\mathrm{pH} \mathrm{6.5)}$. The gel was stained with 
Coomassie brilliant blue R-250 solution and then bleached in acetic acid solution (45\%) and methanol (45\%) [12].

\section{Hydrolysis of hen egg white proteins}

The egg white $(200 \mathrm{~mL})$ was obtained from an organic producer, derived from a sustainable extractive process and harmful to the local ecosystem [15], all collected on the same day and lot, after posture. Then, homogenised in $800 \mathrm{~mL}$ of sodium phosphate buffer (pH 8.0, $50 \mathrm{mM}$ ) for $10 \mathrm{~min}$ under gentle rotation. This protein suspension was subsequently hydrolysed by the protease produced by $A$. avenaceus URM 6706 after its purification. The hydrolysis was performed at the optimum $\mathrm{pH}$ and temperature of the enzyme used $\left(50^{\circ} \mathrm{C}\right.$ and 10.0 , respectively) at a concentration of $1 \%$. Hydrolysis occurred for $24 \mathrm{~h}$, and the aliquots were withdrawn every $4 \mathrm{~h}$. For interruption of the enzymatic hydrolysis, each withdrawn spot was boiled for $10 \mathrm{~min}$ and then held at $-2^{\circ} \mathrm{C}$. Before proceeding with the necessary analyses, the samples were centrifuged to obtain only the soluble peptides $[16,17]$.

\section{Determination of the degree of hydrolysis}

The degree of hydrolysis obtained was considered as the percentage of cleaved peptide bonds determined by the quantification of free amino groups with 2,4,6-trinitrobenzene sulphonic acid (TNBS), according to the methodology described by Adler-Nissen [18]. The total number of amine groups was determined in a completely hydrolysed chicken egg white protein (10 mg) sample per $4 \mathrm{~mL}$ of $6 \mathrm{M} \mathrm{HCl}$ for $24 \mathrm{~h}$ at $110^{\circ} \mathrm{C}$.

\section{Antioxidant activities}

\section{ABTS $^{+}$Radical-Scavenging Activity Test}

The $\mathrm{ABTS}^{+\cdot}$ radical was constituted by potassium persulphate $(2.45 \mathrm{mM})$ and $\mathrm{ABTS}(7 \mathrm{mM})$ and incubated under light for $16 \mathrm{~h}$ at $30^{\circ} \mathrm{C}$. Using the S22 Libra spectrophotometer (Biochrom ${ }^{\circ}$, Austria), the $\mathrm{ABTS}^{+\cdot}$ radical solution was adjusted to an absorbance of $0.70 \pm 0.02$ at $734 \mathrm{~nm}$ by dilution with $100 \mathrm{mM}$ phosphate-buffered saline (PBS) $(\mathrm{pH} \mathrm{7.4)}$. For the reaction, $50 \mu \mathrm{L}$ of the hydrolysate was mixed with $950 \mu \mathrm{L}$ of the solution of the $\mathrm{ABTS}^{\circ+}$ radical. The assays were incubated at $30^{\circ} \mathrm{C}$ for $6 \mathrm{~min}$ and read at $734 \mathrm{~nm}$ in a spectrophotometer (Biochrom Libra S6®, Cambridge, UK) [19]. The antioxidant activity (\%) was calculated in relation to the radical elimination activity according to the following equation:

$$
\text { ABTS radical inhibition }(\%)=\frac{A_{\text {control }}-A_{\text {sample }}}{A_{\text {control }}} \times 100
$$

Where $A_{\text {control }}$ represents the initial absorbance of the ABTS solution, and $A_{\text {sample }}$ shows the absorbance of the assay with the hydrolysate samples.

\section{DPPH Radical-Scavenging Activity Test}

The free radical-scavenging capacity of $\mathrm{DPPH}^{*}$ was measured according to the method described by $\mathrm{Li}$ et al. [20], with some modifications. Then, $50 \mu \mathrm{L}$ of the sample was added to $500 \mu \mathrm{L}$ of $0.1 \mathrm{mM}$ DPPH solution (solubilised in $95 \%$ methanol). The mixture was homogenised and incubated for $30 \mathrm{~min}$ at room temperature and protected from light. The absorbance of the resulting solution was read at $517 \mathrm{~nm}$ in a spectrophotometer (Biochrom Libra S6®, Cambridge, UK), where lower absorbance represented a greater DPPH'-elimination activity. The elimination effect was expressed as shown in the following equation:

$$
\mathrm{DPPH}^{\cdot} \text { radical inhibition }(\%)=\frac{A_{\text {control }}-A_{\text {sample }}}{A_{\text {control }}} \times 100
$$

Where $A_{\text {control }}$ represents the initial absorbance of the DPPH' solution, and $A_{\text {sample }}$ shows the absorbance of the assay with the hydrolysate samples. 


\section{Copper-Chelating Activity}

The $\mathrm{Cu}^{2+}$-chelating activity of the hydrolysate was determined using pyrocatechol violet (PV), according to the methodology of Saiga et al. [21], with few modifications. The reaction mixture of $500 \mu \mathrm{L}$ of acetate buffer $(50 \mathrm{mM}$ and $\mathrm{pH} 6.0)$ and $12.5 \mu \mathrm{l}$ of $\mathrm{CuSO}_{4}(5 \mathrm{mM})$ was added to $125 \mu \mathrm{L}$ of the samples. After $30 \mathrm{~min}$ of incubation at room temperature, $12.5 \mu \mathrm{L}$ of pyrocatechol violet at $4 \mathrm{mM}$ was added. After $30 \mathrm{~min}$, the absorbance was measured at $632 \mathrm{~nm}$ in a spectrophotometer (Biochrom Libra S6®, Cambridge, UK), with distilled water as a control. The percent inhibition (\%) of the formation of the $\mathrm{PV}-\mathrm{Cu}^{2+}$ complex was calculated by the following equation:

$$
\mathrm{Cu}^{2+} \text { chelating activity }(\%)=\frac{A_{\text {control }}-A_{\text {sample }}}{A_{\text {control }}} \times 100
$$

Where $A_{\text {control }}$ represents the absorbance of the assay with distilled water in place of the sample, and $A_{\text {sample }}$ shows the absorbance of the assay with the hydrolysate samples.

\section{Iron-Chelating Activity}

The $\mathrm{Fe}^{2+}$-chelating activity was determined by the inhibition of ferrozine- $\mathrm{Fe}^{2+}$ complex formation, according to Carter [22], with some modifications. The samples (125 $\mu \mathrm{L})$ were mixed in $0.5 \mathrm{~mL}$ of sodium acetate buffer $(0.1 \mathrm{M}$ and $\mathrm{pH} 4.9)$ and $12.5 \mu \mathrm{L}$ of iron (II) chloride. After 30 min of incubation at room temperature, $50 \mu \mathrm{L}$ of ferrozine $(5 \mathrm{mM})$ was added. After an additional $30 \mathrm{~min}$, the absorbance was measured at $562 \mathrm{~nm}$ in a spectrophotometer (Biochrom Libra $\mathrm{S} 6{ }^{8}$, Cambridge, UK). The percent inhibition of ferrozine-Fe ${ }^{2+}$ complex formation was calculated according to the following equation:

$$
F e^{2+} \text { chelating activity }(\%)=\frac{A_{\text {control }}-A_{\text {sample }}}{A_{\text {control }}} \times 100
$$

Where $A_{\text {control }}$ represents the initial absorbance of the assay with distilled water in place of the sample, and $A_{\text {sample }}$ shows the absorbance of the assay with the hydrolysate samples.

\section{Statistical analysis}

All assays were done in triplicate, and the standard deviation was calculated between the three results obtained. The correlation coefficient between the degree of hydrolysis and the antioxidant activities was calculated by the programme Statistica version 7.0 (StatSoft Inc).

\section{RESULTS}

\section{Purification of protease produced by A. avenaceus URM 6706}

The alcoholic precipitation was efficient in the pre-purification of the protease produced by A. avenaceus URM 6706 , with the fraction of $60 \%-80 \%$ ethanol being the most effective for the separation of the enzyme from the contaminants. After precipitation with ethanol, the specific protease activity increased to 2,374.3 U. $\mathrm{mg}^{-1}$ (Table 1), which represents a purification factor of 2.9 times, and the yield was $79.5 \%$.

Table 1. Purification of protease produced by A. avenaceus URM 6706.

\begin{tabular}{lllll}
\hline Applied Protease & TA $\left(\mathbf{U} \cdot \mathbf{m L}^{-1}\right)$ & EA $\left(\mathbf{U} \cdot \mathbf{m g}^{-1}\right)$ & PF & Y (\%) \\
\hline Crude extract & $255.37 \pm 2.79$ & $812.41 \pm 3.05$ & $1.00 \pm 0$ & $100.00 \pm 0$ \\
Ethanol precipitation & $202.79 \pm 2.09$ & $2374.39 \pm 44.1$ & $2.91 \pm 0.17$ & $79.52 \pm 0.82$ \\
lon exchange & $103.33 \pm 2.69$ & $13,659.00 \pm 30.1$ & $16.82 \pm$ & 40.43 \\
chromatography & & & $40.52 \pm 0.33$ \\
\hline
\end{tabular}

AT: Total Activity, AE: Especific Activity, PF: Purification Factor, Y: Yield.

After ion exchange chromatography ( $Q$ Sepharose FF), the purification factor increased to 16.82 , and the yield was $40 \%$ (Table 1). The chromatographic profile is presented in Figure 1 , 
where four different protein peaks and four peaks of enzymatic activity can be visualised. It shows that in the highest peak of enzymatic activity (Peak 1), the lowest protein peak was obtained, as well as the reverse; therefore, the peak with better purification and yield values. These values can be considered very good for a purified enzyme.

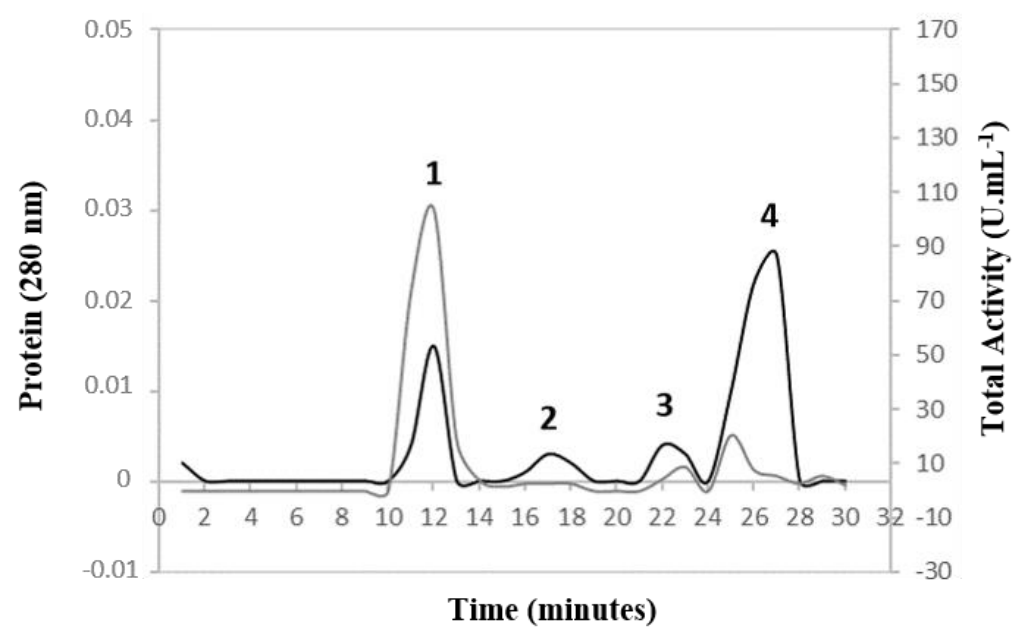

Figure 1. Chromatogram of ion exchange in $Q$ Sepharose FF column of the protease produced by Aspergillus avenaceus URM 6706. Grey line: Total protease activity $(S D= \pm 0.001 ; \pm 0.002 ; \pm 0.0005$; \pm 0.0005 for peaks $1,2,3$ and 4 ; respectively); Black line: Protein at $280 \mathrm{~nm}(\mathrm{SD}= \pm 0.226 ; \pm 1.667$; $\pm 0.957 ; \pm 1.447$ for peaks $1,2,3$ and 4 ; respectively).

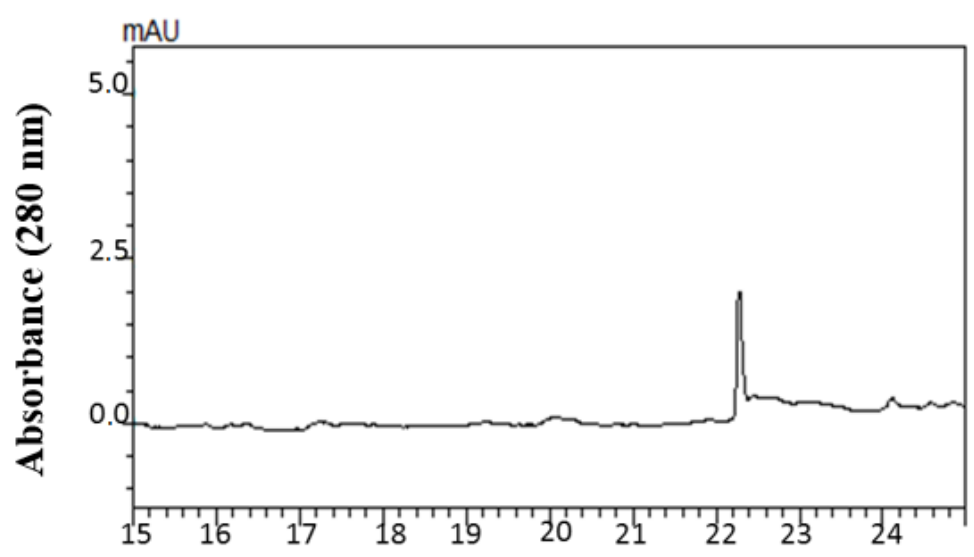

Time (minutes)

Figure 2. Purity analysis of the protease produced by Aspergillus avenaceus URM 6706 by HPLC.

The protease under study was analysed for its electrophoretic profile at each purification step; it can be seen that in the crude enzymatic extract, nine bands with molecular weights ranging from 17.89 to $82.48 \mathrm{kDa}$ were present (Figure 3). The amount of these bands was decreased at each purification step, with three bands after alcohol precipitation and only one band after the ion exchange chromatography with a molecular weight of $35.27 \mathrm{kDa}$. The hydrolytic activity of albumin can be verified by the zymogram (Figure 3E). 


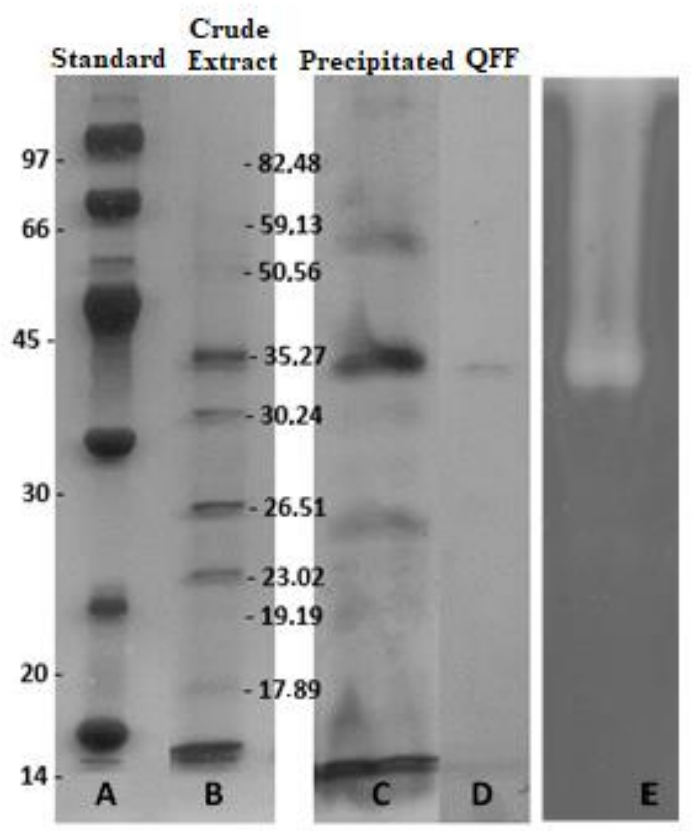

Figure 3. SDS-PAGE of the protease produced by Aspergillus avenaceus URM 6706. (A): molecular weight markers; (B): crude enzymatic extract; (C): extract precipitated with ethyl alcohol (60-80\%), (D): extract purified by ion exchange chromatography and (E): zymogram (albumin) of the extract purified by ion exchange chromatography.

\section{Optimum temperature and $\mathrm{pH}$ determination}

The purified protease produced by $A$. avenaceus URM 6706 had an optimum pH of 10.0 (using carbonate-bicarbonate buffer). In general, the enzyme presented the lowest activity at acidic $\mathrm{pH}$, with activities below $30 \%$ and up to $7 \%$ at $\mathrm{pH} 5.0$. In the $\mathrm{pH}$ range from neutral to alkaline, the activity was raised until it decreased again to almost $50 \%$ at $\mathrm{pH} 11.00$ (Figure 4).

The purified enzyme produced by $A$. avenaceus URM 6706 showed $50^{\circ} \mathrm{C}$ as the optimum temperature for protease activity (Fig 5 ). Up to $60^{\circ} \mathrm{C}$, the enzyme exhibited protease activity of above $40 \%$, and this activity considerably decreased from $70^{\circ} \mathrm{C}$.

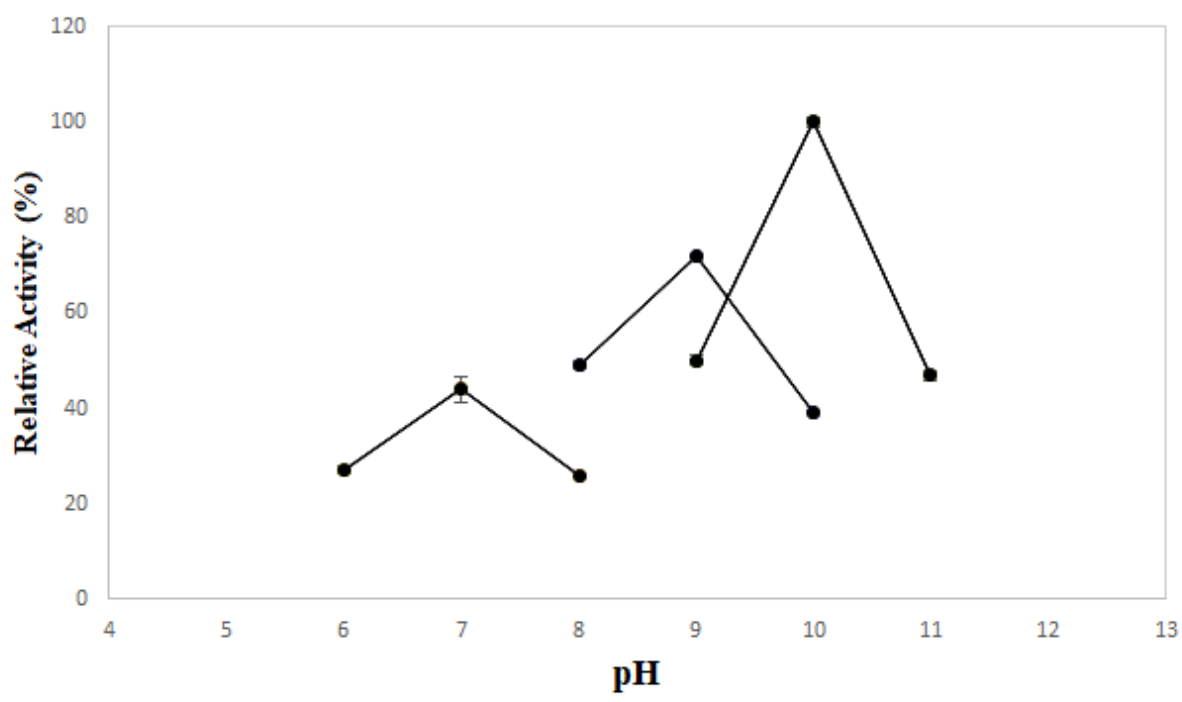

Figure 4. Optimum pH curve of the purified protease produced by Aspergillus avenaceus URM 6706. 


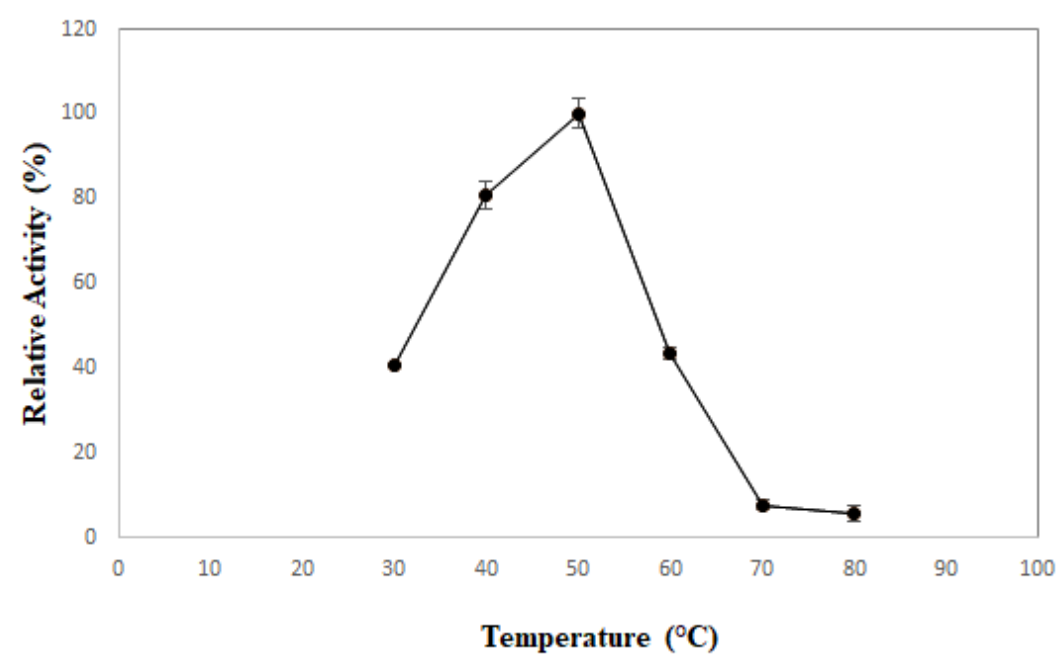

Figure 5. Optimum temperature curve of the purified protease produced by A. avenaceus URM 6706.

\section{Hydrolysis of hen egg white proteins and antioxidant activities}

During proteolysis, it is necessary that the optimal conditions required by the enzyme employed be maintained for efficient peptide release [30]. Therefore, according to the optimum $\mathrm{pH}$ and temperature obtained in the protease assays obtained by $A$. avenaceus URM 6706, the hydrolysis of hen egg white was performed at $\mathrm{pH} 10.0$ and $50^{\circ} \mathrm{C}$. It can be seen that this hydrolysis was directly proportional to the time (Table 2), ranging from $46 \%$ ( $4 \mathrm{~h}$ of hydrolysis) to $69 \%$ (24 h of hydrolysis).

Table 2. Relation of the degree of hydrolysis of hen egg white with antioxidant activities.

\begin{tabular}{|c|c|c|c|c|c|}
\hline $\begin{array}{c}\text { Time of } \\
\text { hydrolysis }(h)\end{array}$ & Degree of hydrolysis & DPPH $^{\circ}$ & ABTS $^{+}$ & $\mathrm{Cu}^{+2}$ chelating & $\mathrm{Fe}^{+2}$ chelating \\
\hline $\begin{array}{c}\text { hydrolysis (h) } \\
4: 00\end{array}$ & & $27.09+2.441$ & $\begin{array}{c}(\%) \\
97.77+0.427\end{array}$ & $62.38+0.547$ & $54.90+1.540$ \\
\hline $8: 00$ & $49.38 \pm 0.211$ & $3.99 \pm 2.335$ & $99.67 \pm 0.133$ & $0.00 \pm 1.691$ & $0.00 \pm 1.617$ \\
\hline $12: 00$ & $57.04 \pm 0.121$ & $0.00 \pm 3.184$ & $99.61 \pm 0.203$ & $0.00 \pm 0.447$ & $0.00 \pm 1.861$ \\
\hline & $.38 \pm 0.121$ & $0.00 \pm 3.794$ & $99.83 \pm 0.133$ & $0.00 \pm 2$ & $0.00 \pm 1.452$ \\
\hline 00 & $63.68 \pm 0.715$ & $0.00 \pm 3.687$ & $99.72 \pm 0.384$ & $1.72 \pm 1.542$ & $0.00 \pm 1.540$ \\
\hline $24: 00$ & $69.71+0.990$ & $0.00 \pm 1.910$ & $99.78 \pm 0.203$ & $13.10 \pm 1.677$ & $0.00 \pm 0.924$ \\
\hline
\end{tabular}

$\mathrm{DPPH}^{\circ}$ : Radical-Scavenging Activity Test, $\mathrm{ABTS}^{++}$: Radical-Scavenging Activity test, $\mathrm{Cu}^{+2}$ chelating:

Copper-Chelating Activity, $\mathrm{Fe}^{+2}$ chelating: Iron-Chelating Activity.

Table 3. Correlation between the degree of hydrolysis and the different antioxidant activities in percentage of the protein hydrolysate of chicken egg white.

\begin{tabular}{|c|c|c|c|c|c|}
\hline & Degree of hydrolysis & DPPH $^{\circ}$ & ABTS *+ & $\mathrm{Cu}^{+2}$ chelating & $\mathrm{Fe}^{+2}$ chelating \\
\hline Degree of hydrolysis & 1.00 & -0.73 & 0.60 & -0.55 & -0.67 \\
\hline DPPH & - & 1.00 & -0.90 & 0.85 & 0.90 \\
\hline ABTS $^{++}$ & - & - & 1.00 & -0.88 & -0.93 \\
\hline $\mathrm{Cu}^{+2}$ chelating & - & - & - & 1.00 & 0.96 \\
\hline $\mathrm{Fe}^{+2}$ chelating & - & - & - & - & 1.00 \\
\hline
\end{tabular}

Regarding the elimination of the $\mathrm{ABTS}^{*+}$ radical, the correlation with the degree of hydrolysis can be considered as strong and positive $(\rho=0.6)$. The ABTS ${ }^{\circ+}$ radical-elimination activity is strongly correlated with the other antioxidant activities studied, but in a negative way, which indicates that as the antioxidant activity against the ABTS ${ }^{+}$radical increases, the others decrease. In turn, all other antioxidant activities studied are strongly correlated positively. 


\section{Purification of protease produced by A. avenaceus URM 6706}

The results found in this study are highly promising when compared with protease purification studies, which, in the first step of the purification, often achieve a purification factor very close to 1 . For example, the protease produced by $A$. parasiticus was pre-purified by precipitation with acetone, with a purification factor of 1.28 and a yield of $33.8 \%$ [16]. The milk coagulant protease produced by Termitomyces clypeatus MTCC 5091 was precipitated with ammonium sulphate, but the purification factor obtained was not reported and the yield in this first purification step was $34.15 \%$ [23].

The protease produced by $A$. parasiticus [16] had a purification factor of 2.19 and a yield of $2.47 \%$ after three steps of purification. Whereas the protease produced by $T$. clypeatus MTCC 5091 obtained a very high purification factor of 33.62 times after four purification methods, which may increase the costs associated with the enzyme purification, in addition to having a yield of only $3.41 \%$ [23]. Moreover, after four purification steps, the serine protease produced by A. fumigatus was purified 8.8 times and had a yield of $6.6 \%$ [24].

Enzymatic purification represents an important step in the industrial production process of enzymes, since this step represents about $50 \%-80 \%$ of the total costs related to this activity. This high cost is generally associated with the several steps necessary for the purification of these biomolecules. Therefore, a high purification factor and a high yield can represent a production and purification of enzymes that can be applied in a large scale at a low cost [25]. In this case, by the analysis method of purity employed in this study, it was possible to confirm the presence of only one protein that was represented by a single peak (Figure 2).

The literature reports about proteases of Aspergillus sp. with varied molecular weights, such as A. oryzae MTCC 5341 of $34 \mathrm{kDa}$ [26], A. fumigatus of $88 \mathrm{kDa}$ [24] and A. parasiticus of $36 \mathrm{kDa}[16]$.

\section{Optimum temperature and $\mathrm{pH}$ determination}

The best activity at alkaline $\mathrm{pH}$ confirms its potential for application in the production of protein hydrolysates originating from egg white, since egg white has an alkaline $\mathrm{pH}$ above 8.5 [27].

The proteases of microbial origin have a variable $\mathrm{pH}$; for example, the purified protease produced by $A$. parasiticus presented optimum activity at $\mathrm{pH} 7.0$ [16], and the proteases produced by $A$. terreus gr [28] and $A$. oryzae $\mathrm{CH} 93$ [29] also presented optimum activity at alkaline $\mathrm{pH} 11.0$ and 8.0 , respectively.

The results obtained in this study are in agreement with those obtained by Niyonzima \& More [28] and Salihi et al. [29] who also observed the optimum temperature of activity for the proteases produced by $A$. terreus gr and $A$. oryzae $\mathrm{CH} 93$, respectively.

Regarding the application of proteases in the hydrolysis of egg white, it is interesting that the temperature applied is not high to avoid denaturation and consequently coagulation of the white proteins, and hence, the optimum temperature of $50^{\circ} \mathrm{C}$ of the protease produced by $A$. avenaceus URM 6706 is convenient for this application.

\section{Hydrolysis of hen egg white proteins and antioxidant activities}

It is known that fungal proteases exhibit a higher substrate specificity and promote a higher degree of hydrolysis when compared with those by bacterial proteases, for example, which have already been described as promoting a low degree of hydrolysis in food proteins [31].

When performed by a single enzyme, the proteolysis reaction is maintained under optimal conditions of the enzyme until completion, which generally ranges from 1 to $24 \mathrm{~h}$, depending on the desired characteristics of the product obtained. The duration of the hydrolysis has an inverse relationship with the size of the peptide, but in most cases, a constant size is reached, which, even with a high increase in the hydrolysis time, will have no effect on the size or activity of the peptide [30]. In the present study, probably, the increase in the time of hydrolysis beyond that tested could still intensify the obtained hydrolysis; however, the cost of hydrolysate 
production would also be proportional to this increase. In addition, based on the values of the antioxidant activities obtained (Table 2), it is noticed that a higher degree of hydrolysis is not required.

In the present study, it was possible to determine the effect of egg hydrolysis on the production of egg products. They are effective against the enzymatic and non-enzymatic peroxidation of lipids and essential fatty acids, as well as the elimination of free radicals and the chelation of metallic ions [32]. In addition, antioxidant peptides from food sources are considered safe, healthy compounds with low molecular mass, low cost, high activity and easy absorption [33].

In inhibiting the oxidative processes, the action of antioxidant peptides, besides being important for the preservation of cells in an organic system, is of great importance for the quality and preservation of food. The formation of free radicals results in deterioration of the food quality, for example, the rancid flavour, which, in addition to causing the products to be rejected by the consumers, is related to the reduction of the shelf life. Another factor that intensifies the inhibition of oxidative processes in foods is the relationship that several studies have shown between the intake of foods containing lipid oxidation products and the development of diseases such as cancer, diabetes and cardiovascular diseases [34].

In general, the antioxidant activities presented by peptides are influenced by molecular mass and molecular structure, and it has been reported that low molecular weight peptides have antioxidant properties [35]. However, when the degree of hydrolysis is very high, the functional properties of the peptide may be negatively affected. For example, emulsifying capacity and emulsion stability were more present when the degree of hydrolysis was lower for some research. Besides, levels and compositions of free amino acids and peptides can determinate the antioxidant activities of protein hydrolysates [7]. Smaller peptides are able to migrate faster and adsorb at the interface, but are not efficient at decreasing interface tension by not being large enough to unfold and reorient at the interface and thus stabilize the emulsion [36].

Which can be applied to DPPH radical elimination activity obtained in this research, which was lower in peptides originated from a higher hydrolysis as well as to the iron-chelating activity, which implies that the lower the molecular mass of the hydrolysates, the lower the antioxidant capacity, which can also be seen in other studies that show a decrease in antioxidant activity with increasing degree of hydrolysis [37].

For the $\mathrm{ABTS}^{\circ+}$ radical-scavenging activity, the intensity of the hydrolysis appeared to influence the activity; however, after $8 \mathrm{~h}$ of hydrolysis, this activity was constant. Hydrolysis inhibited the copper-chelating activity, which was $62 \%$ when $46 \%$ was hydrolysed, $0 \%$ between $49 \%$ and $69 \%$ of hydrolysis and reappeared after $60 \%$ of hydrolysis with $1.7 \%$ chelating activity (Table 2).

This correlation between the degree of hydrolysis and the antioxidant activity can be better visualised in Table 3. The data confirm that the correlations between the degree of hydrolysis and the elimination activity of the DPPH radical, with the $\mathrm{Cu}^{2+}$ and with the $\mathrm{Fe}^{2+}$, were all negative. This indicates that the more hydrolysed the hen eggs are, the lower these activities will be, with correlation coefficients of $-0.73,-0.55$ and -0.67 , respectively, with a higher correlation for DPPH and $\mathrm{Fe}^{2+}$.

The DPPH radical is a stable free radical that shows the maximum absorbance at $517 \mathrm{~nm}$ in ethanol and has been widely used to test the ability of the natural compounds to act as free radical scavengers or hydrogen donors as a method of assessing their potential antioxidants. When the DPPH radical encounters a proton donor substance as an antioxidant, the radicals will be eliminated and the absorbance will be reduced [38-39].

Protein hydrolysates and peptides originating from egg white have been reported as capable of eliminating the DPPH radical [40-31]. Peptides derived from ostrich egg white hydrolysis studied by Tanzadehpanah et al. [41], for example, presented a DPPH radicalelimination activity of up to $81 \%$, but in that same work, it was observed that the degree of hydrolysis positively influenced the antioxidant activity that was increased by the higher degree of hydrolysis of the egg white.

Opposite results to those obtained in the study in which a higher activity of the elimination of the DPPH radical (from $37.2 \%$ to $64.2 \%$ ) and a lower elimination of the ABTS ${ }^{\circ+}$ (from $1.91 \%$ 
to $2.82 \%$ ) radical were observed in the activity of peptides originating from the egg white by the action of lysozyme [40].

$\mathrm{ABTS}^{++}$, in turn, is a relatively stable radical but easily reduced by antioxidants. The elimination activity against the $\mathrm{ABTS}^{\circ+}$ cationic radical indicates the ability of protein hydrolysates as electron donors or hydrogen donors in reactions with the free radical [42]. Still in relation to the ostrich egg white peptides, an $\mathrm{ABTS}^{-+}$-elimination activity of up to $62.7 \%$ was observed. The low ABTS ${ }^{++}$-elimination capacity may be a result of the low solubility of some peptide aqueous solutions. Therefore, some peptides or protein hydrolysates have strong antioxidant ABTS system, but not in the lipid-soluble system (DPPH) [43], which was observed for the hydrolysates of hen egg white.

The antioxidant activity of protein hydrolysates can not be attributed to a single mechanism. The peptides can be effective and exhibit specific binding with metal ions [44-41], since in their molecules, there may be several binding sites with the metals. The chelation of metal ions has an antioxidant effect because iron and copper transition metals promote oxidative damage at different levels [21]. These in vivo oxidative reactions appear to be involved in the pathogenesis of at least some neurodegenerative diseases [45]. Copper, for example, is capable of producing reactive oxygen species, causing breaks in the DNA chain and oxidation of nucleotide bases [46].

For poultry egg white hydrolysates, copper chelation was $62 \%$ at $46 \%$ clear degree of hydrolysis. With the intensification of the hydrolysis, however, up to $59 \%$ of this oxidative capacity was lost and reappeared after $63 \%$ of hydrolysis (Table 2 ). The amino acid sequence may alter the biological activity of the peptides [47], which would explain why this activity disappeared at a certain degree of hydrolysis. However, with the continuity of the hydrolysis, the modification in the peptide molecule made possible the reappearance of the same.

For the proteins of Phaseolus vulgaris L. var. Jamapa, the hydrolytic treatment increased the copper-chelating activity from $0 \%$ to $35 \%$, with a general tendency of increasing copperchelation activity with the hydrolysis time, although this activity decreased when lectin hydrolysates were tested (isolates from $P$. vulgaris L. var. Jamapa) after 90 and 120 min of hydrolysis [48].

Of the several transition metals, iron is known to be an effective lipid oxidation factor due to its high reactivity. In the Fenton reaction involving $\mathrm{Fe}^{2+}\left(\mathrm{Fe}^{2+}+\mathrm{H}_{2} \mathrm{O}_{2} \rightarrow \mathrm{Fe}^{3+}+\mathrm{OH}^{-}+\mathrm{OH} \cdot\right)$, there is the release of hydroxyl radical. The $\mathrm{Fe}^{3+}$ ion also produces radicals from peroxides, although the formation rate is 10 times lower than that of the $\mathrm{Fe}^{2+}$ ion [49].

For hen egg white hydrolysates, iron chelation was 59\% when the degree of hydrolysis was at $46 \%$. The activity, however, decreased as the degree of hydrolysis intensified. This event can be explained by the hydrolysis of ovotransferrin, which is a monomeric glycoprotein consisting of 686 amino acids and represents $12 \%$ of the total egg white protein [50]. Iron can easily be bound to ovotransferrin [51], being a natural antimicrobial characteristic of the egg. Therefore, it may be suggested that as ovotransferrin hydrolysis occurs, its iron-binding capacity reduces.

The peptides obtained by the hydrolysis of ostrich egg white showed an iron-chelating activity of up to $30 \%$; however, it is noteworthy that these peptides were partially purified [52].

In general, the longer the hydrolysis time, the lower the antioxidant activity; that is, the more peptides released by the enzymatic action, the lower their antioxidant capacity. This may be explained by the fact that lower concentrations of peptides may support intramolecular interactions, a situation in which a metal center can be linked to different sites of the same peptide molecule. On the other hand, in a solution with higher concentration of peptides, the intermolecular interactions can become more frequent, suggesting the ability of a metal to bind to one or more sites of different peptide molecules. This may be happening as result of increased competition for binding to the free metal caused by high concentration of peptides [53].

\section{CONCLUSION}

The new protease purified from Aspergillus avenaceus URM 6706 was able to hydrolyse egg white and release peptides with different antioxidant activities; its partial characterization has demonstrated that the hydrolysis can be carried out under appropriate conditions for 
industry, not requiring large investments to maintain optimal conditions of enzymatic action. The hydrolysis of chicken egg white was positively affected by the exposure time to pure protease produced by $A$. avenaceus URM 6706, but this correlation was not always positive in relation to the time of hydrolysis and the antioxidant activities. It can be said that the hydrolysates obtained from the egg white of organic chicken present diverse antioxidant activities, being able to be applied industrially as a functional food that presents multiple biological activities.

Funding: This research was funded by FACEPE (Process APQ-0460.2.01/15) and CAPES.

\section{REFERENCES}

1. Sharma S, Singh R, Rana S. Bioactive peptides: a review. Int J Bioautomat. 2011;15:223-50.

2. Chalamaiah M, Jyothirmayi T, Bhaskarachary K, Ajreswari A, Hemalatha R, Kumar D. Chemical composition, molecular mass distribution and antioxidante capacity of rohu (Labeo rohita) roe (egg) protein hydrolysates prepared by gastrointestinal proteases. Food Res Int. 2013;52:221-9.

3. Manso MA, Miguel M, Even J, Hernández R, Aleixandre A, López-Fandiño R. Effect of the long-term in take of an egg white hydrolysate on the oxidative status and blood lipid profile of spontaneously hypertensive rats. Food Chem. 2008;2:441-8.

4. Miguel M, Gomez-Ruiz J, Recio I, Aleixandre A. Changes in arterial blood pressure after single oral administration of milk-casein-derived peptides in spontaneously hypertensive rats. Mol Nutr Food Res. 2010;54:1422-7.

5. Huang W, Majumder K, Wu J. Oxygen radical absorbance capacity of peptides from egg white protein ovotransferrin and their interaction with phytochemicals. Food Chem. 2010;123:635-41.

6. Chen C, Chi YJ, Zhao MY, LV L. Purification and identification of antioxidant peptides from egg white protein hydrolysate. Amino Acids. 2012;41:457-66.

7. Nimalaratne $\mathrm{C}$, Bandara N, Wu J. Purification and characterization of antioxidant peptides from enzymatically hydrolyzed chicken egg white. Food Chem. 2015;188:467-72.

8. Bhat ZF, Kumar SK, Bhat HF. Bioactive peptides of animal origin a review. J Food SciTechnol. 2015;52:5377-92.

9. Castro RJS, Sato HH. A response surface approach on optimization of hydrolysis parameters for the production of egg White protein hydrolysates with antioxidante activities. Biocatal Agr Biotechnol. 2015;4:55-62.

10. Li X, Luo $\mathrm{Y}$, Shen $\mathrm{H}$, You J. Antioxidant activities and functional properties of grass carp (Ctenopharyng odonidellus) protein hydrolysates. J Sci Food Agric. 2012;2:292-8.

11. Ghorbanpur M, Zare Mirakabadi A, Zokaee F, Zolfagarrian H, Rabiei H. Purification and partial characterization of a coagulant serine protease from the venom of the iranian snake Agkistrodon halys. J Venom Anim Toxins Incl Trop Dis. 2009;3:411-23.

12. Leighton TJ, Doi RH, Warren RAJ, Kelln RA. The Relationship of serine protease activity to RNA polymerase modification and sporulation in Bacillus subtilis. J Mol Biol Mol. 1973;76:103-22.

13. Bradford MMA. Rapid and sensitive method for the quantitation of microgram quantities of protein utilizing the principle of protein-dye binding. Anal Biochem. 1976;72:248-54.

14. Laemmli UK. Cleavage of structural proteins during the assembly of the head of bacteriophage T4. Nat. 1970;227:680-5.

15. Brasil. Decreto $n^{\circ}$ 6.323, de 27 de dezembro de 2007. Regulamenta a Lei $n^{\circ} 10.831$, de 23 de dezembro de 2003, que dispõe sobre a agricultura orgânica, e dá outras providências. Diário Oficial [da] República Federativa do Brasil. 2003 dez 23. Capítulo I, Artigo 2o․

16. Anitha TS, Palanivelu P. Purification and characterization of an extracellular keratinolytic protease from a new isolate of Aspergillus parasiticus. Protein Expr Purif. 2013;88:214-20.

17. Silva AC, Queiroz AESF, Oliveira JTC, Medeiros EV, Souza-Motta CM, Moreira KA, inventors. 2017. Método para obtenção de hidrolisados de clara de ovo de galinha de capoeira com atividade antioxidante. Brazilian patent BR 102017017706 8. 2017 Aug 17.

18. Adler-Nissen J. Determination of the degree of hydrolysis of food protein hydrolysates by trinitrobenzenesulfonic acid. J Agric Food Chem. 1979;27:1256-62.

19. Re R, Pellegrini N, Proteggente A, Pannala A, Yang M, Rice-Evans E C. Antioxidant activity applying an improved ABTS radical cation decolorization assay. Free Radic Biol Med. 1999;26:1231-7. 
20. Li Y, Jiang B, Zhang T, Mu W, Liu J. Antioxidant and free radical scavenging activities of chickpea protein hydrolysate (CPH). Food Chem. 2008;106:444-50.

21. Saiga A, Tanabe S, Nishimura T. Antioxidant activity of peptides obtained from porcine myofibrillar proteins by protease treatment. J Agric Food Chem. 2003;51:3661-7.

22. Carter P. Spectrophotometric determination of serum iron at the submicro-gram level with a new reagent (ferrozine). Anal Biochem. 1971;40:450-8.

23. Majumder R, Banik SP, Khowala S. Purification and characterisation of k-casein specific milk-clotting metalloprotease from Termitomyces clypeatus MTCC 5091. Food Chem. 2015;173:441-8.

24. Hernández-Martínez R, Gutiérrez-Sánchez G, Bergmann CW, Loera-Corral O, Rojo-Domínguez A, Huerta-Ochoa S, Regalado-González C, Prado-Barragán LA. Purification and characterization of a thermodynamic stable serine protease from Aspergillus fumigatus. Process Biochem. 2011;46:20016.

25. Hernández MS, Rodríguez MR, Guerra NP, Rosés RP. Amylase production by Aspergillus niger in submerged cultivation on two wastes from food industries. J Food Process Eng. 2006;73:93-100.

26. Vishwanatha KS, Rao AGA, Singh SA. Production and characterization of a milk-clotting enzyme from Aspergillus oryzae MTCC 5341. Appl Microbiol Biotechnol. 2010;85,1849-59.

27. Vilela DR, Carvalho LSS, Fagundes NS, Fernandes EA. Internal and External Quality of commercial laying hens eggs with normal and vitreous eggshell. Ciênc Anim Bras. 2016;17:509-51.

28. Niyonzima FN, More SS. Purification and characterization of detergent-compatible protease from Aspergillus terreus gr. 3 Biotech. 2015;5:861-70.

29. Salihi A, Asoodeh A, Aliabadian M. Production and biochemical characterization of an alkaline protease from Aspergillus oryzae CH93. 2017. Int J Biol Macromol. 2017;94:827-35.

30. Aluko RE. Antihypertensive Peptides from Food Proteins. Annu Rev Food Sci Technol. 2015;6:23562.

31. Castro RJS, Sato HH. A response surface approach optimization of hydrolysis parameters for the production of egg white protein hydrolysates with antioxidant activities. Biocatal Agric Biotechnol. 2015;4:55-62.

32. Bhat ZF, Kumar S, Bhat HF. Bioactive peptides of animal origin: a review. J Food Sci Technol. 2015;52:5377-92.

33. Sarmadia BH, Ismail A. Antioxidative peptides from food proteins: A review. Peptides. 2010;10:194956.

34. Ryan JT, Ross RP, Bolton D, Fitzgerald GF, Stanton C. Bioactive peptides from muscle sources: meat and fish. Nutrients. 2011;9:765-91.

35. Sheih I, Fang $T$, Wu T. Isolation and characterization of a novel angiotensin I converting enzyme (ACE) inhibitory peptide from the algae protein waste. Food Chem. 2009;115:279-84.

36. Klompong V, Benjakul S, Kantachote D, Shahidi F. Antioxidative activity and functional properties of protein hydrolysate of yellow stripe trevally (Selaroides leptolepis) as influenced by the degree of hydrolysis and enzyme type. Food Chem. 2007;102:1317-27.

37. Theodore AE, Raghavan S, Kristinsson HG. Antioxidative activity of protein hydrolysates prepared from alkaline-aided channel catfish protein isolates. J Agric Food Chem. 2008;56:7459-66.

38. Zhu KX, Zhou HM, Qian HF. Antioxidant and free radical-scavenging activities of wheat germ protein hydrolysates (WGPH) prepared with alcalase. Process Biochem. 2006;41:1296-302.

39. Yang $\mathrm{P}, \mathrm{Ke} \mathrm{H}$, Hong $\mathrm{P}$, Zeng $\mathrm{S}$, Cao W. Antioxidant activity of big eye tuna (Thunnus obesus) head protein hydrolysate prepared with alcalase. Int J Food Sci Technol. 2011;46:2460-6.

40. Memarpoor-Yazdi M, Asoodeh A, Chamani J. A novel antioxidant and antimicrobial peptide from hen egg white lysozyme hydrolysates. J Funct Foods. 2012;4:278-86.

41. Tanzadehpanah $\mathrm{H}$, Asoodeh A, Saberi MR, Chamani J. Identification of a novel angiotensin-I converting enzyme inhibitory peptide from ostrich egg white and studying its interactions with the enzyme. Innov Food Sci Emerg Technol. 2013;18:212-9.

42. Prior RL, Wu X, Schaich K. Standardized methods for the determination of antioxidant capacity and phenolics in foods and dietary supplements. J Agric Food Chem. 2005;53:4290-302.

43. Zhu L, Chen C, Tang X, Xiong Y. Reducing, radical scavenging, and chelation properties of in vitro digests of Alcalase-treated zein hydrolysate. J Agric Food Chem. 2008;56:2714-21.

44. Sovago I, Osz K. Metal ion selectivity of oligopeptides. Dalton Transactions. 2006;32:3841-54. 
45. Mandel S, Amit T, Reznichenko L, Weinreb O, Youdim M BH. Green tea catechins as brainpermeable, natural iron chelators-antioxidants for the treatment of neurodegenerative disorders. Mol Nutr Food Res. 2006;71:249-57.

46. Megias C, Pedroche J, Yust MM, Giron-Calle J, Alaiz M, Millan F, Vioque J. Affinity purification of copper chelating peptides from chickpea protein hydrolysates. J Agric Food Chem. 2007;10:394954 .

47. Guo L, Harnedy P, Li B, Hou H, Zhang Z, Zhao X, Fitzgerald RJ. Food protein-derived chelating peptides: Biofunctional ingredients for dietary mineral bioavailability enhancement. Trends Food Sci Technol. 2014;37:92-105.

48. Carrasco-Castilla J, Hernández-Álvarez AJ, Jiménez-Martínez $C$, Jacinto-Hernández $C$, Alaiz M, Girón-Calle J, Vioque J, Dávila-Ortiz G. Antioxidant and metal chelating activities of Phaseolus vulgaris L. var. Jamapa protein isolates, phaseolin and lectin hydrolysates. Food Chem. 2012;131:1157-64.

49. Gülçin İ. Antioxidant and antiradical activities of L-carnitine. Life Sci. 2006;8:803-11.

50. Stadelman WJ, Cotterill OJ. Egg Science and Technology. 4th ed. Westport (CT): Avi Publ. Co.; 2001.

51. Ko KY, Ahn DU. An economic and simple purification procedure for the large scale production of ovotransferrin from egg white. Poult Sci. 2008;7:1441-50.

52. Tanzadehpanah $\mathrm{H}$, Asoodeh A, Chamani J. An antioxidant peptide derived from Ostrich (Struthio camelus) egg white protein hydrolysates. Food Res Int. 2012;1:105-11.

53. Melo MMM, Daniele-Silva A, Texeira DG, Estrela AB, Melo KRT, Oliveira VS, Rocha HAO, Ferreira LS, Pontes DL, Lima JPMS, Silva-Júnior AA, Barbosa EG, Carvalho E, Fernandes-Pedrosa MF. Structure and in vitro activities of a Copper II-chelating anionic peptide from the venom of the scorpion Tityus stigmurus. Peptides. 2017;94:91-8. 